\title{
FIELD NOTE: Nature-Based Tourism Operators' Responses to Changing Environment and Climate in Uis, Namibia
}

\begin{abstract}
Namibia, one of the driest countries in sub-Saharan Africa, has great potential as a nature-based tourism destination, but is also vulnerable to the impacts of global environmental and climate change. In this study the perceptions of tourism businesses in Tsiseb conservancy of the potential impacts of climate change to their operations, and their adaptation plans are analyzed. The results show agreement with recent climate change, but future change is considered to happen with less certainty. The operators believe that climate change impacts tourism industry, but not their own businesses. As a consequence, no concrete adaptation methods have been developed.
\end{abstract}

Keywords: nature-based tourism, environmental change, climate change, adaptation, Namibia

\section{Introduction}

Tourism is increasingly used as a vehicle for various social and economic goals in southern Africa and many countries in the region have identified tourism and especially nature-based tourism as an important strategy for rural development (Ashley \& Roe, 2002; Rogerson, 2002), conservation of natural and cultural resources (Moswete \& Dube, 2013; Saarinen, Becker, Manwa \& Wilson, 2009; Shoo \& Sorongwa, 2013) and for poverty alleviation among the rural poor and previously marginalized local communities (Ashley, 1998; Barnes, 2008; King, 2004; Rogerson, 2006; Saarinen \& Rogerson, 2014). Also in Namibia the nature-based tourism industry is considered to have high potential for creating employment and generating revenue (Republic of Namibia, 2012; Lapeyre, 2010; Snyman, 2012), and the governmental development policies, especially in rural areas, highlight the role of community-based natural resource management (CBNRM) with emphasized tourism development component (MET, 2008).

Namibia is endowed with a rich natural resource base: the wildlife, their habitats and natural landscapes, in general, form a major component for the touristic attractiveness of the country. Therefore, Namibia is considered to have great potential as a nature-based tourism destination (Ashley \& Barnes, 1997, Barnes, 2008; Snyman, 2014; Weaver \& Elliot 1996). Consequently, 
different types of nature-based tourism form the basis of tourism activities in the country, especially in the conservancies. As described by Bollig (2016), tourism industry in the conservancies mainly consist of (small scale) tourism lodges and campsites, craft centers, and providers of nature-related and hunting tourism activities. In 2015, tourism was estimated to account for 15.5 percent of total Gross Domestic Product (GDP) with a forecast to rise by 5.0 percent in 2016 (WTTC, 2016). This makes the industry as the second most important sector (in GDP) in Namibia, after mining. According to the World Travel and Tourism Council (WTTC) (2016), the total contribution of tourism to employment, including jobs indirectly supported by the industry was 17.1 percent of total employment (136,000 jobs) and foreign visitor expenditures generated 10.8 percent of total exports in 2015.

However, while tourism plays an important and an increasing role for the socio-economic development of the country (Barnes, 2008; MET, 2010, Silva \& Motzer, 2014), there are emerging challenges. Namibia is one of the driest countries in sub-Saharan Africa, and the estimated impacts of global climate change may create major impacts for the country's tourism industry, as especially nature-based tourism is considered highly vulnerable to the impacts of global environmental and climate change (MET, 2015). This makes the increasingly tourism-dependent rural communities also more vulnerable.

Although climate change studies in tourism have increased during the last 10 years, there still remains geographical imbalance between regions, and regional knowledge gaps especially in Africa and Asia are evident (D'Amore \& Kalifungwa, 2013; Becken, 2013; Reddy \& Wilkes, 2013). In addition, the Future Climate for Africa (2016), in a recent report, emphasizes the geographical knowledge gaps in climate science in southern Africa, as well as the vulnerability of the societies and economies in the area. Indeed, a research article search (with keywords 'Africa', 'tourism' and 'climate change', for example) provides only a handful of articles discussing climate change from the point of view of tourism (see. e.g. Fitchett, Grant \& Hoogendoorn, 2016; Fitchett, Hoogendoorn \& Swemmer, 2016; Rogerson, 2016; Saarinen, Hambira, Atlhopheng \& Manwa, 2012), and none of them addresses tourism-climate change nexus in Namibia

This piloting field note paper aims to fill these knowledge gaps in evolving African and especially Namibian climate change and tourism studies. This is important, as research conducted elsewhere, for example in northern Europe (Brouder \& Lundmark, 2012; Tervo, 2008) has shown that vulnerability is highly contextual. For example, the type of tourism activities, dependence on tourism, and local climate conditions are important factors defining the overall vulnerability of a tourist destination. This paper aims to examine how tourism businesses that are deeply linked with nature-based tourism products perceive the potential impacts of environmental and climate change 
to their operations and business environment(s) and what is their willingness to adapt to these perceived changes. Methodologically, we aim to study whether the entrepreneurs are able to identify specific adaptation measures needed in future. The results of the study increase geographical knowledge about climate change vulnerability in tourism, but also provide data for comparison studies to develop the southern African knowledge base further.

The specific case site in Namibia is a small town called Uis, which is located in the Tsiseb communal conservancy. In Namibia, a conservancy refers to a territorial unit where natural resource management and utilization activities are undertaken by a group of local people that has organized itself based on the governmental guidelines and under a management committee (see Kavita \& Saarinen, 2016; Lapeyre, 2011). These conservancies are custodians of the natural resources, mainly wildlife, within their boundaries, which they can utilize for attracting tourists in a sustainable way (see Blaikie, 2006; Massyn, 2007). Therefore, although the interviewed entrepreneurs are based in Uis, the paper focuses on the impacts of environmental and climate change in the context of the whole Tsiseb conservancy. The main research question is: how changing environment and, more specifically, climate change are perceived to affect the tourism operations in the conservancy?

\section{Climate Change in Namibia}

In Namibia, situated in south-western coast of Africa, climate is generally hot and dry, with sparse and erratic rainfall (MET, 2010). More than ninety percent of the land area is hyper-arid, arid or semi-arid. The high variability of rainfall and the various climatic zones in the country make the prediction and detection of climatic trends difficult, and decrease the usability of variables such as mean precipitation. According to the Intergovernmental Panel on Climate Change (IPCC, 2014), the mean surface temperature increase in southern Africa is likely to exceed the global mean increase. The projected warming of 3.4 to 4.2 degrees Celsius is expected to take place especially in the semi-arid and arid regions of Namibia, parallel to precipitation decrease. Together these changes will have profound impacts on the natural resources and their utilization. The changes in climatic patterns lead to changes in the spatial distribution of agro-ecological zones, habitats, distribution of plant diseases and pests and fish populations (Chishakwe Murray \& Chambwera, 2012). Because of the country's high dependence on industries that rely on natural resources (according to MET, 2010, half of the population is dependent on natural resources for income), Namibia has been stated to 
have limited capacity to adapt to the impacts of climate change (Government of Namibia 2002, cited in Reid et al., 2007: 7-8).

Interestingly, the country's climate policy from year 2010 does not recognize the potential impacts of the aforementioned changes to tourism (MET, 2010). In addition, the country's proposed climate change action plan (Mfune et al., 2009) only refers to tourism by mentioning that the tourists' presence threatens the conservation of coastal zones and causes pressure to resources in these areas. According to the climate policy, the effects of climate change are meaningful especially for agriculture, human health and well-being, energy, infrastructure, biodiversity and ecosystems. However, as tourism relates with many of these sectors, it is clear that also tourism sector will face impacts, e.g. in relation to droughts and water scarcity, shifting of malaria zones, rising temperatures, power shortages and shifting of the vegetation zones. Nonetheless, as climate change knowledge and awareness in the country - especially in relation to potential risks and opportunities - are considered to be low, it is understandable that complexity of climate change related impacts remains unknown. For the same reason, most climate change related planning to increase resilience to climate change and implementation of policies is currently in its early stage and reactive by nature (MET, 2010).

Therefore, there is an urgent need for research that can provide sectoral (and cross-sectoral) knowledge of the potential impacts of climate change and the related environmental change on the country. Moreover, the country aims to strengthen and develop disaster risk management, and Ministry of Environment and Tourism states this being its 'frontline defence in adapting to impacts of climate change' (MET, 2010: 21). However, no studies exist concerning the future of Namibia's tourism in the light of changing climate, nor is there research-based knowledge available about the adaptive capacity of the Namibian tourism industry to respond to the changes.

\section{Case Study Area and Methods}

The study was carried out in Uis, a small town located in Erongo region in Namibia, approximately 360 kilometers north-west from the country's capital, Windhoek (Figure1). Uis is the main (population) center in the Tsiseb conservancy where most of the services are located. The town is an old tin mining community next to the Brandberg, which is the highest mountain in the country.

Uis and the surrounding Conservancy are renowned for their natural and cultural resources. The conservancy was registered in 2001 and besides the wildlife, the area lures tourists with cultural heritage attractions; e.g. the famous rock painting called the White Lady is located in the area. The 
conservancy is a large arid area (803 300 hectares) that receives an average rainfall ranging from 9 $\mathrm{mm}$ to $150 \mathrm{~mm}$ annually with a very high rate of evaporation (Lapeyre, 2010).

Figure 1 about here.

The empirical research material consisting interviews was collected in June 2014. The interviews were based on a semi-structured research instrument, and all tourism-related businesses in the town were approached and asked to participate in the study. The research instrument consisted of a survey form that included both open-ended and closed questions. It was designed on the basis of the authors' previous research of this topic in different geographical contexts. Face-toface contact was preferred as other methods to reach the local businesses (e.g. mail, email) were considered unreliable and/or not realizable. As the responses for the semi-structured interviews were rather short in nature, they were analyzed utilizing a basic content analysis. All the responses were collected together and similarities and dissimilarities as well as common themes were searched for. Due to the small number of responses, no quantification of the results was done, even though the numbers of certain remarks were counted as shown in the following section.

\section{Results}

\section{Tourism-related businesses in the study area}

In total, 9 out of the 10 businesses in the area agreed to participate in the study. They represented different kind of operations; hence also their peak seasons varied (Table1). None of the businesses operated in hunting tourism. For most (7/9) of the interviewees the main customers were international tourists who arrive to the area by car (self-drive or package tours). For wildlife management operators the customer base mainly consisted of Namibians. All the businesses were small or micro enterprises, employing 1-18 people.

Table 1 about here.

\section{Perceptions of Environmental Change}


All the interviewees stated they had experienced some environmental changes during the last five years. These changes were mostly related to climate or weather conditions; with both rain and drought mentioned by two thirds (6/9) of the respondents. Changes in rain refer to the erratic character of rains; that is, changes in the timing and amount of precipitation, while drought equals with increasing/longer/more severe dry seasons. Other environmental changes were the destruction of roads (caused by self-driving tourists), poaching and the growth of the town (Table 2).

Seven of the interviewees agreed with the idea that climate is changing, and their experiences and knowledge about the impacts of climate change for their businesses were covered more thoroughly. Three interviewees had the opinion that climate change has had no impact on his/her business and activities, at least not yet (Table 2). They represented both management/wildlife care and souvenir sales. The others mentioned that human-wildlife conflicts and drought (which leads to decrease in customer numbers) had impacted their businesses, i.e. restaurant/accommodation and management/wildlife care. According to one interviewee, also operating a restaurant/accommodation business, the impacts so far have been positive as his experience was that the number of travelers is higher during rainy times. One of the interviewees who agreed with the idea that climate is changing had no opinion or experience about the impacts on his own business.

Table 2 about here.

\section{Perceptions of Changing Climate}

All the interviewees were asked to rate their level of agreement with certain climate change related statements. Seven of the interviewees agreed to do so (including the two that earlier disagreed with the idea that climate is changing)(Figure 2).

Figure 2 about here.

As shown in Figure 2, the statement 'Climate change will impact tourism industry' received the highest level of agreement while the statement 'Climate change will reduce the attractiveness of tourism products in the region in the future' was most disagreed. These views can be considered to be in contradiction, unless the interviewees perceived the impacts of the change to be mainly positive. Examination of the distribution differences for the statements reveals that wide variation exists i.e. the interviewees' understandings and considerations about climate change vary a lot: 
opposing views are expressed for all but two statements: 'Climate change will impact tourism industry' and 'Recent temperatures and rains have been normal'.

\section{Local Responses to Change: Vulnerability and Adaptation}

In relation to vulnerability of attractions and activities, wildlife and vegetation were considered most vulnerable (mentioned 2 times) while fishing industry, mining and mountain climbing were each mentioned by one interviewee. Wildlife was considered vulnerable as the animals lack food during the droughts. Fishing industry's vulnerability was explained with the temperature rise affecting the fish. This may hinder also fishing tourism activities, even though Tsiseb is not known for fishing. Mountain climbing was considered to suffer from loss of tourists. One of the interviewees had the opinion that (tourist) 'attractions have adapted to desert climate' and that 'only swimming activities are reduced' because of climate change. As the respondent owned a swimming pool, the comment may have related with the increasing costs of maintaining a swimming pool. None of the interviewees considered his/her own activity to be among the most vulnerable activities, except for the one management/wildlife care representative expressing concern for 'wild animals'.

When discussing the implications of the abovementioned issues for future growth of their businesses, three of the interviewees mentioned issues that concerned them. They included effects on wildlife as because of uncertain precipitation, the source of income (i.e. wildlife) is not able to survive. This means less income, or, as the respondent stated: "less money coming in". However, one interviewee saw that as people know what to expect, the impacts of changing climate will not affect the businesses' future growth. Another interviewee had the opinion that changing climate will not have any implications yet. However, she was not able or willing to estimate the potential future impacts.

Adaptation perspectives or methods were not widely evident (Table 3). Altogether 4 of the 9 interviewees mentioned some adaptation methods that were put in place to cope with environmental change. The methods were not very concrete apart from the investment on swimming pool and air conditioning and the provision of water for animals suffering from drought. Rather, the adaptation was more conceptual, without direct implications, and targeted to political and governmental agencies. In addition, two of the interviewees who had realized some adaptation, reported on adaptation measures they had failed to adopt for some reason. These included the diversification of income sources and the plans to increase patrolling in the region. 
Table 3 about here.

\section{Discussion and Conclusions}

Most of the interviewed businesses demonstrated knowledge and observations of some environmental changes in the region. Similar to climate change studies elsewhere in southern Africa (see Fitchett, Hoogendoorn \& Swemmer, 2016; Hambira, Saarinen, Manwa et Althopheng, 2013), the observed changes were mostly related to climate or weather conditions that include rain and drought. This could be because Namibia by nature and geography is a desert country, where lower level of precipitation may easily lead to drought and have severe implications. The occurrence of these kinds of conditions causes concern and is easily remarked. Also, their potential implications are well-understood, maybe because of earlier experiences.

Majority of the operators agreed with the statement that climate has recently changed in the region. However, more than half of the respondents considered that recent temperatures and rains have been normal, and they were doubtful about the future climate change. In addition, even though the majority believed that climate change will impact tourism industry, less than half of the respondents considered it to affect their own businesses, and even fewer agreed with the statement 'climate change will reduce the attractiveness of tourism products in the region in the future'.

This contradiction between the ideas of climate change impacting tourism industry but not reducing the attractiveness of tourism products in the region can reflect the understanding of climate change as something that does not concern 'me' directly. Similar understandings have been reported in other studies, where the local industry has been considered resistant or immune to impacts (Hambira et al. 2013; see also Saarinen \& Tervo, 2006). In addition, since the majority of the respondents admitted they were unsure about the impacts caused by climate change, it is possible that they simply were not able to predict the ways in which tourism industry could be affected in their region. This remains so, even though the implications of climate change to wildlife and vegetation, the fishing industry and activities such as mountain climbing were considered to be harmful. The positivism could also derive from the operators being well aware of the reasons of tourists to come visit Uis: they are interested in participating and seeing desert-related tourism activities, natural and cultural landscapes and history (see Lapeyre, 2010; MET, 2010), which may not necessarily be affected by the change in the near future.

The lack of concrete, visible adaptation methods, as well as the presented statement about the importance of conveying information to the public signals two issues. First, there is dire need 
for further research on climate change adaptation in Namibia. Secondly, although the operators are the experts of their businesses it may not be realistic to assume that they have the needed adaptive capacity and that they are able to identify and develop needed adaptation measures by themselves without external support and information. In addition, they may need advice in order to avoid maladaptation and adaptation that does not support climate change mitigation. For example the swimming pool and air conditioning mentioned by one of the respondents are counterproductive in terms of mitigation. Thus, the findings of this piloting study may help guide further research on climate change and its impacts on tourism and related political ecologies in Namibia. Eventually it is important that they lead to the development of adaptation strategies, and give insights to ongoing policy and decision making in tourism and related sectors that are ultimately linked to the vulnerability of rural communities in future.

\section{References}

Ashley, C. (1998). Tourism, communities and national policy: Namibia's experience. Development Policy Review, 16, 323-353.

Ashley, C. \& Barnes, J. (1997). Wildlife use for economic gain: The potential for wildlife to contribute to development in Namibia. In Smith, F. (Ed.), Environmental sustainability: Practical global applications (pp 163-192). Roca Baton: CRC Press.

Ashley, C. \& Roe, D. (2002). Making Tourism work for the poor: strategies and challenges in southern Africa. Development Southern Africa, 19, 61-82.

Barnes, J. (2008). Community-based tourism and natural resource management in Namibia: Local and national economic impacts. In Spenceley, A. (Ed.), Responsible tourism: Critical issues for conservation and development (343-360). London: Earthscan.

Becken, S. (2013). A review of tourism and climate change as an evolving knowledge domain. Tourism Management Perspectives, 6, 53-62. doi:10.1016/j.tmp.2012.11.006.

Blaikie, P. (2006). Is small really beautiful? Community-based natural resource management in Malawi and Botswana. World Development, 34, 1942-1957. 
Bollig, M. (2016). Towards an Arid Eden? Boundary making, governance and benefit sharing and the political ecology of the "new commons" of Kunene Region, Northern Namibia. International Journal of the Commons 10(2), 771-799.

Brouder, P. \& L. Lundmark (2012). Climate change in Northern Sweden: intra-regional perceptions of vulnerability among winter-oriented tourism businesses. Journal of Sustainable Tourism, 19(8), 919-933.

Chishakwe, N., Murray, L. \& Chambwera, M. (2012). Building climate change adaptation on community experiences: Lessons from community-based natural resource management in southern Africa. London: International Institute for Environment and Development.

D'Amore, L., \& Kalifungwa, P. (Eds). (2013). Meeting the challenges of climate change to tourism: Case studies of best practice. Newcastle: Cambridge Scholars.

Fitchett, J. M., Grant, B. \& Hoogendoorn, G. (2016). Climate change threats to two low-lying South African coastal towns: risks versus perceptions. South African Journal of Science, 112(5/6). DOI: http://dx.doi.org/10.17159/sajs.2016/20150262

Fitchett, J.M., Hoogendoorn, G. \& Swemmer, A. M. (2016). Economic costs of the 2012 floods on tourism in the Mopani District Municipality, South Africa. Transactions of the Royal Society of South Africa, 71. DOI: org/10.1080/0035919X.2016.1167788.

Future Climate for Africa (2016). Africa's climate. Helping decision-makers make sense of climate information. November 2016. Retrieved from http://www.futureclimateafrica.org/wpcontent/uploads/2016/11/africas-climate-final-report-4nov16.pdf.

Hambira, W., Saarinen, J., Manwa, H. \& Atlhopheng, J. (2013). Climate change adaptation practices in nature-based tourism in Maun in the Okavango Delta area, Botswana: how prepared are the tourism businesses? Tourism Review International, 17, 19-29. http://dx.doi.org/10.3727/154427213X13649094288025. 
IPCC (2014). IPCC WGII AR5 Glossary. Retrieved from http://ipccwg2.gov/AR5/images/uploads/WGIIAR5-Glossary_FGD.pdf.

Kavita, E. \& Saarinen, J. (2016). Tourism and rural community development in Namibia: Policy issues review. Fennia, 194(1), 79-88.

King, B. (2004). The state of NGOs in post-apartheid South Africa: Changing roles in conservation and development. African Geographical Review, 23(1), 65-84.

Lapeyre, R. (2010). Community-based tourism as a sustainable solution to maximize impacts locally: the Tsiseb conservancy case, Namibia. Development Southern Africa, 27(5), 757-772.

Massyn, P. J. (2007). Communal land reform and tourism investment in Namibia's communal areas: a question of unfinished business? Development Southern Africa 24(3), 381-392. http://dx.doi:10.1080/03768350701445384.

MET (2008). National tourism policy for Namibia. Draft (Sept 2007). Windhoek : Government of Namibia.

MET (2010). National policy on climate change for Namibia. Windhoek : Government of Namibia.

MET (2015). Namibia third national communication to the United Nations framework convention on climate change. Windhoek : Government of Namibia.

Mfune, J. K., Ruppel, O.C., Willemse, N. E. \& Mosimane, A. W. (2009). Proposed climate change strategy and action plan. Windhoek: Versacon.

Moswete N, Dube OP. 2013. Wildlife-based tourism and climate: Potential opportunities and challenges for Botswana. In: D’Amore L, Kalifungwa P. (Eds.), Meeting the challenges of climate change to tourism: Case studies of best practice (pp. 395-416). Newcastle: Cambridge Scholars.

Reddy, M. V. \& Wilkes, K. (2013). Tourism, climate change and sustainability. London: Routledge. 
Reid H., Sahlén. L., MacGregor, J. \& Stage, J. (2007). The economic impact of climate change in Namibia: How climate change will affect the contribution of Namibia's natural resources to its economy. London: International Institute for Environment and Development.

Republic of Namibia (2012). Namibia's fourth national development plan, NPD_4,2012/13 2016/2017. Retrieved from http://www.npc.gov.na/?wpfb_dl=37.

Rogerson, C. (2002). Tourism-led local economic development: the South African experience. Urban Forum, 13(1), 95-119.

Rogerson, C. (2006). Pro-poor local economic development in South Africa: The role of pro-poor tourism. Local Environment, 11(1), 37-60.

Rogerson, C. (2016). Climate change, tourism and local economic development in South Africa. Local Economy, 31(1-2), 322-331.

Saarinen J, Becker F, Manwa, H. \& Wilson, D. (Eds). (2009). Sustainable tourism in Southern Africa: Local communities and natural resources in transition. Bristol: Channel View.

Saarinen, J. Hambira, W. Atlhopheng, J. \& Manwa, H. (2012). Perceived impacts and adaptation strategies of the tourism industry to climate change in Kgalagadi South District, Botswana. Development Southern Africa, 29(2), 273-285.

Saarinen, J. \& Rogerson, C. M. (2014). Tourism and the millennium development goals: perspectives beyond 2015. Tourism Geographies, 16(1), 23-30. http://dx.doi: 10.1080/14616688.2013.851269.

Saarinen, J. \& Tervo, K. (2006) Perceptions and adaptation strategies of the tourism industry to climate change: the case of Finnish nature-based tourism entrepreneurs. International Journal of Innovation and Sustainable Development, 1, 214-228. 
Shoo, R. \& Sorongwa, A. (2013). Contribution of ecotourism to nature conservation and improvement of livelihoods around Amani nature reserve, Tanzania. Journal of Ecotourism, 12(2), 75-89.

Silva, J. A. \& Motzer, N. (2014). Hybrid uptakes of neoliberal conservation in Namibian tourismbased development. Development and Change 46(1): 48-71. DOI: 10.1111/dech.12139.

Snyman, S. L. (2012). The role of tourism employment in poverty reduction and community perceptions of conservation and tourism in southern Africa. Journal of Sustainable Tourism, 20(3), 395-416.

Snyman, S. (2014). Assessment of the main factors impacting community members' attitudes towards tourism and protected areas in six southern African countries. Koedoe, 56(2). doi: 10.4102/koedoe.v56i2.1139.

Tervo, K. (2008). The operational and regional vulnerability of winter tourism to climate variability and change: the case of the nature-based tourism entrepreneurs in Finland. Scandinavian Journal of Hospitality and Tourism, 8(4), 317-332.

Weaver, D. \& Elliot K. (1996). Spatial patterns and problems in contemporary Namibian tourism. The Geographical Journal 162(2), 205-217.

WTTC (2016). Travel \& Tourism: Economic impact 2016 Namibia. London: WTTC. Retrieved from http://www.wttc.org//media/files/reports/economic\%20impact\%20research/countries\%202016/namibia2016.pdf. 
Table 1. Characteristics of the interviewed businesses.

\begin{tabular}{|c|c|c|c|c|c|}
\hline $\begin{array}{l}\text { Sector } \\
\text { according to } \\
\text { main operation }\end{array}$ & Activities & Customers & $\begin{array}{c}\text { Years of } \\
\text { operation in } \\
\text { the area }\end{array}$ & $\begin{array}{c}\text { Number } \\
\text { of } \\
\text { employees }\end{array}$ & High season \\
\hline $\begin{array}{l}\text { Restaurant/ } \\
\text { accommodation }\end{array}$ & Accommodation, catering & $\begin{array}{l}\text { Intl. and domestic } \\
\text { tourists }\end{array}$ & 9 & 17 & Jul-Dec \\
\hline Activities & $\begin{array}{l}\text { Hot air ballooning, sundown } \\
\text { and elephant drives, } \\
\text { accommodation }\end{array}$ & $\begin{array}{l}\text { Intl. tourists (South } \\
\text { Africa, Europe) }\end{array}$ & 7 & 7 & Aug-Nov \\
\hline $\begin{array}{l}\text { Restaurant/ } \\
\text { accommodation }\end{array}$ & Cafeteria & $\begin{array}{l}\text { Intl. tourists } \\
\text { (Germany, Canada, } \\
\text { USA) }\end{array}$ & 0 & 3 & No info \\
\hline $\begin{array}{l}\text { Restaurant/ } \\
\text { accommodation }\end{array}$ & Restaurant, catering & $\begin{array}{l}\text { Intl. tourists } \\
\text { (France) }\end{array}$ & 3 & 6 & May-Aug \\
\hline $\begin{array}{l}\text { Craft retail and } \\
\text { production }\end{array}$ & Souvenir production and sale & $\begin{array}{l}\text { Intl. tourists } \\
\text { (Germany) }\end{array}$ & 18 & 3 & May-Nov \\
\hline $\begin{array}{l}\text { Management/ } \\
\text { wildlife care }\end{array}$ & $\begin{array}{l}\text { Conservancy, looking after } \\
\text { wildlife, training, ventures } \\
\text { with local businesses }\end{array}$ & $\begin{array}{l}\text { Intl. tourists } \\
\text { (Germany, Asia, } \\
\text { Switzerland) }\end{array}$ & 14 & 10 & Jun-Dec \\
\hline Activities & $\begin{array}{l}\text { Tour guiding, sharing } \\
\text { information }\end{array}$ & $\begin{array}{l}\text { Intl. tourists } \\
\text { (Germany) }\end{array}$ & 4 & 0 & Jun-Aug \\
\hline $\begin{array}{l}\text { Management/ } \\
\text { wildlife care }\end{array}$ & $\begin{array}{l}\text { Resource management, } \\
\text { community assistance, } \\
\text { wildlife monitoring }\end{array}$ & Locals (Namibian) & 1 & 5 & $\begin{array}{l}\text { No high } \\
\text { season }\end{array}$ \\
\hline $\begin{array}{l}\text { Management/ } \\
\text { wildlife care }\end{array}$ & $\begin{array}{l}\text { Wildlife management, } \\
\text { fieldwork, training, flora and } \\
\text { fauna management, research, } \\
\text { patrolling and controlling }\end{array}$ & Locals (Namibian) & 1 & 5 & $\begin{array}{l}\text { May-Jul, } \\
\text { Dec }\end{array}$ \\
\hline
\end{tabular}


Table 2. Experienced environmental changes in Uis.

\begin{tabular}{lc}
\hline Environmental changes & Frequency of mentions \\
\hline Drought & 6 \\
\hline Rain & 6 \\
\hline Destruction to roads & 1 \\
\hline Town is growing & 1 \\
\hline Poaching & 1 \\
\hline Experienced impact of climate change on own business & 1 \\
\hline Drought, no rain fall, less customers & 3 \\
\hline Human-wildlife conflicts & 1 \\
\hline No impact (not yet, nothing) & 1 \\
\hline Positive impact, more travelers during rainy times & \\
\hline
\end{tabular}


Table 3. References to adaptation activities among respondents.

\begin{tabular}{ll}
\hline Method & Type of operation \\
\hline Convey information from the director of environmental affairs to the public & Management/wildlife care \\
Top level ministry is responsible & Management/wildlife care \\
\hline Medical plans & \\
Climate change policy & Management/wildlife care \\
\hline Provide water for animals & Restaurant/accommodation \\
\hline Swimming pool and AC & \\
\hline
\end{tabular}


Figure 1. Map of the study area.

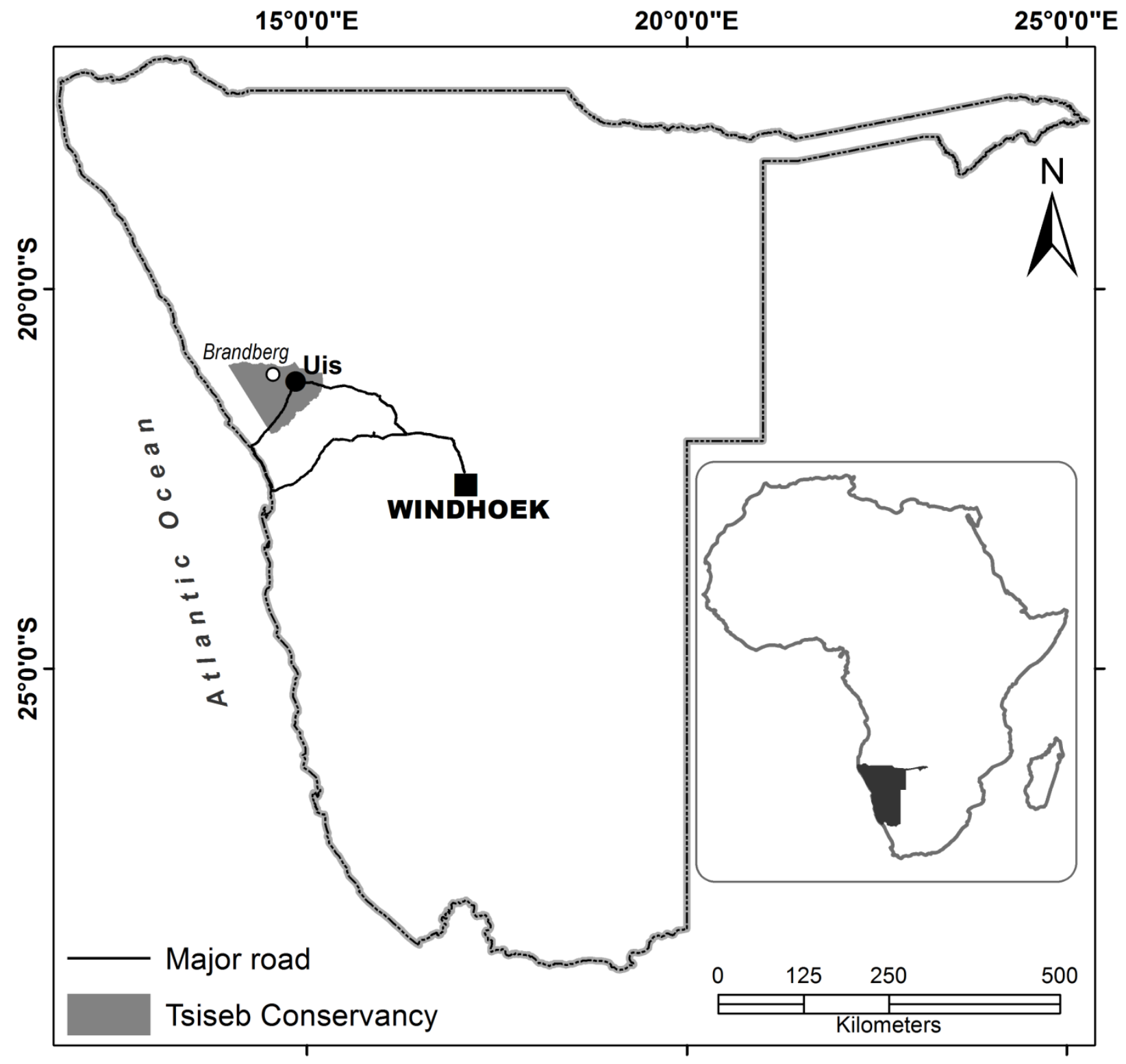


Figure 2. Distribution of the level of agreement with climate change related statements among interviewees $(\mathrm{N}=7)$.

Climate has recently changed in my region Climate will change in future in my region Climate change will impact tourism industry Climate change will not impact our operations Tourism businesses should invest on adaptation now Climate change will impact negatively to wild life Recent temperatures and rains have been normal Climate change will reduce the attractiveness of tourism products... I don't know what impacts climate change will bring

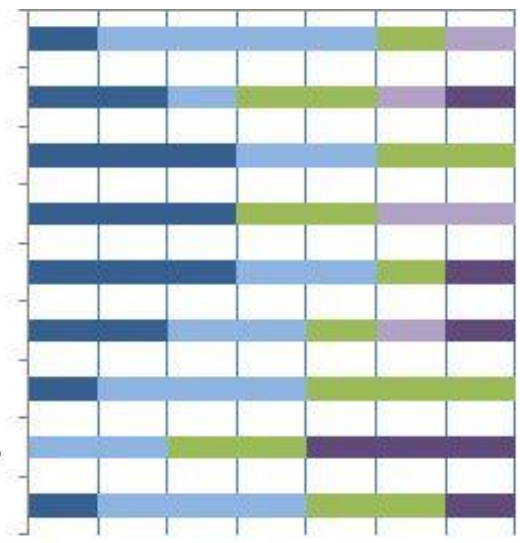

- Strongly agree

agree

Neither agree or disagree Disagree

- Strongly disagree

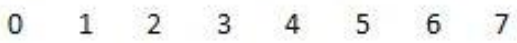

